\title{
Cyclin E/cdk2 and cyclin A/cdk2 kinases associate with p107 and E2F in a temporally distinct manner
}

\author{
Emma Lees, ${ }^{1,3}$ Barbara Faha, ${ }^{1}$ Vjekoslav Dulic, ${ }^{2}$ Steven I. Reed, ${ }^{2}$ and Ed Harlow ${ }^{1}$ \\ ${ }^{1}$ Massachusetts General Hospital Cancer Center, Charlestown, Massachusetts 02129 USA; ${ }^{2}$ Department of Molecular \\ Biology, The Scripps Research Institute, La Jolla, California 92037 USA
}

\begin{abstract}
Cyclin $E$ is classified as a putative $G_{1}$ cyclin on the basis of its cyclic pattern of mRNA expression, with maximal levels being detected near the $G_{1} / S$ boundary. We report here that cyclin $E$ is found associated with the transcription factor E2F in a temporally regulated fashion. E2F is known to be a critical transcription factor for the expression of some $S$ phase-specific proteins and is thought to be important for a series of others. Antisera specific for cyclin $E$ were raised and used to demonstrate an association between cyclin $E$ and E2F. This cyclin E/E2F complex was seen in a variety of human cell lines from various tissues, but its appearance was detected primarily during the $G_{1}$ phase of the cell cycle. The cyclin E/E2F association decreased as cells entered $S$ phase, just as the association of E2F with cyclin $A$ became detectable. We characterized the cyclin E-E2F complex further to show that both the cyclin-dependent kinase-2 (cdk2) and p107 were present. Therefore, the p107/E2F complex is associated with two different cdk2 kinase complexes-one containing cyclin $\mathrm{A}$ and the other containing cyclin $\mathrm{E}$-and the appearance of these complexes is temporally regulated during the cell cycle. The presence of cyclin E/E2F complexes in the $G_{1}$ phase suggests a role for cyclin $E$ in the control of genes required for the $\mathrm{G}_{\mathbf{1}}$-to-S transition.
\end{abstract}

[Key Words: Cell cycle; cyclin E; cdk2; E2F; p107]

Received June 24, 1992; revised version accepted July 21, 1992.

Our understanding of the control of cell division in mammalian cells has stemmed largely from work carried out in other systems, particularly in the analysis of cell cycle control in yeast. Studies both in budding and fission yeast have demonstrated important control points committing cells to enter $S$ phase and mitosis (Hartwell 1973; Nurse 1975). Attempts to identify the proteins regulating these two commitment points have revealed elaborate pathways involving many components. The protein kinase cdc2 (or Cdc28 in Saccharomyces cerevisiae) appears to be required at both regulatory points (Nurse and Bissett 1981; Piggott et al. 1982; Reed and Wittenberg 1990). The activity of this kinase is controlled through association with regulatory subunits known as cyclins (Booher et al. 1989; Draetta et al. 1989; Moreno et al. 1989; Richardson et al. 1989; Wittenberg et al. 1990).

Cyclins were first identified in marine invertebrates as proteins with levels that oscillate dramatically through the cell cycle (Evans et al. 1983; Swenson et al. 1986; Standart et al. 1987; Hunt et al. 1992). These proteins have been well conserved through evolution and play a critical role in the regulation of cellular division /Swenson et al. 1986; Minshull et al. 1989; Murray et al. 1989;

${ }^{3}$ Corresponding author.
Solomon et al. 1990). The $\mathrm{G}_{2} / \mathrm{M}$ transition is dependent on the activity of the cdc2 kinase, the activation of which requires association of cdc2 with B-type cyclins (Booher et al. 1989; Draetta et al. 1989; Moreno et al. 1989). Homologs of this kinase/cyclin complex appear to regulate the $G_{2} / M$ transition in all eukaryotic cells.

In addition to their role in controlling entry into mitosis, cyclins have also been shown to control earlier stages of the cell cycle. In mammalian cells, a cyclin A-associated kinase appears in interphase, probably near the beginning of S phase (Giordano et al. 1989; Pines and Hunter 1990; Pagano et al. 1992b). Microinjection of either antisense oligonucleotides or antibodies against cyclin A causes a block or delay in DNA synthesis (Girard et al. 1991; Pagano et al. 1992b). Other data showing the requirement for cyclin $A$ for entry into mitosis would suggest a later function for cyclin $A$ at the $G_{2} / M$ boundary (Lehner and O'Farrell 1990; Walker and Maller 1991; Pagano et al. 1992b). In S. cerevisiae there are regulatory proteins that clearly control progression through $G_{1}$, by modulating the activity of the cdc2 homolog, $\mathrm{Cdc} 28$ (Reed 1991). These $\mathrm{G}_{1}$ cyclins are known as $C \ln 1, \mathrm{Cln} 2$, and Cln3 (Cross 1988; Nash et al. 1988; Hadwiger et al. 1989; Richardson et al. 1989; Wittenberg et al. 1990) and share limited homology with the mitotic cyclins in the most conserved region of the cyclin protein, known as 
the cyclin box, which is the region required to bind to cdc2 (E. Lees and E. Harlow, in prep.; S. Shiff and E. Harlow, in prep.; H. Kobayashi, E. Stewart, and T. Hunt, pers. comm.).

Until recently, mammalian equivalents to these $G_{1}$ cyclins had not been identified, and it has therefore been unclear whether cyclins have any role to play in controlling $G_{1}$ events in multicellular organisms. Several novel mammalian cyclins- $\mathrm{C}, \mathrm{D} 1$, and $\mathrm{E}-$ have now been isolated by virtue of their ability to rescue loss of CLN function mutations in yeast (Koff et al. 1991; Lew et al. 1991; Xiong et al. 1991). Cyclin Dl was also isolated independently as an amplified region of DNA in parathyroid tumors (Motokura et al. 1991) and as a gene that was stimulated by colony stimulating factor treatment of murine macrophages (Matsushime et al. 1991). Because the mitotic cyclin Bl can also rescue the loss-offunction CLN mutation in yeast, this screen alone is clearly not selective for $G_{1}$ cyclins. However, these new cyclins appear to be good candidates for functioning in $G_{1}$, given the cyclic pattern of their RNA expression with levels peaking at the $\mathrm{G}_{1} / \mathrm{S}$ boundary (Lew et al. 1991; Matsushime et al. 1991; Motokura et al. 1991).

Many issues exist regarding regulation and events that occur in mammalian cells during $G_{1}$ and at the $G_{1} / S$ transition. Of particular importance has been the identification of transcription factors that mediate cell cycledependent gene control. Transcription of a number of genes encoding proteins that are required in $G_{1}$ and $S$ occurs only transiently during $G_{1}$. Therefore, this time is also an important point for transcriptional control /for review, see Pardee 1989). The transcription factor E2F has been implicated in the regulation of such genes. E2Fbinding sites have been identified in the $5^{\prime}$-flanking region of a number of early genes, including c-myc, N-myc, and the dihydrofolate reductase (DHFR) gene and have been shown to be important for their transcription (Blake and Azizkhan 1989; Hiebert et al. 1989, 1991a; Mudryj et al. 1990). The activity of E2F is thought to be tightly regulated by association with other proteins, including the protein product of the retinoblastoma gene $\mathrm{pRB}$ and a structurally related protein, p107 (Bagchi et al. 1991; Bandara and La Thangue 1991; Chellappan et al. 1991; Chittenden et al. 1991; Raychaudhuri et al. 1991; Cao et al. 1992; Shirodkar et al. 1992). Several studies have implicated pRB as a repressor of transcription (Laiho et al. 1990; Pietenpol et al. 1990), and it is speculated that pRB association with E2F prevents transcriptional activity (Bandara and La Thangue 1991; Chellappan et al. 1991; Hiebert et al. 1991b; Raychaudhuri et al. 1991). The existence of a complex between p107, cyclin A, cyclindependent kinase-2 (cdk2), and E2F during $S$ phase suggests a direct involvement of components of the cell cycle machinery in the regulation of E2F (Bandara et al. 1991; Mudryj et al. 1991; Cao et al. 1992; Pagano et al. 1992a; Shirodkar et al. 1992). The timing of the appearance of this cyclin A complex suggests that other regulatory events must control the onset of E2F transcriptional activity in $\mathrm{G}_{1}$.

The newly isolated cyclins are good candidates for such regulators, given the timing of their expression during $G_{1}$ and the precedence for cyclin association with E2F based on observations made for cyclin A. We set out to investigate whether any of the newly isolated cyclins were associated with E2F, particularly during the $G_{1}$ phase of the cell cycle. Using antibodies raised against human cyclin $E$, we have been able to describe a unique activity for cyclin $\mathrm{E}$, which suggests its involvement in the regulation of the transcription factor E2F in a temporally distinct manner from cyclin A.

\section{Results}

\section{Antisera specific for human cyclin $E$}

To study cyclin $E$ and its associated proteins, we raised antibodies specific for cyclin E. To prepare an appropriate immunogen, human cyclin $\mathrm{E}$ was purified from two sources: (1) Full-length cyclin E was synthesized in bacteria from a T7 expression vector [(Studier et al. 1990); the construction of the cyclin $\mathrm{E}$ vector and the methods for purification of the protein are described elsewhere (Dulic et al. 1992)], or (2) a fusion protein between cyclin $\mathrm{E}$ and glutathione $S$-transferase (GST) was purified as described previously (Smith and Johnson 1988). These proteins were used as immunogens in BALB/c mice. Initially, antisera were tested by immunoprecipitation of cyclin $\mathrm{E}$ polypeptides synthesized by in vitro translation of cRNA prepared from the human cyclin E cDNA. Cyclin $\mathrm{E}$ antisera were not able to recognize the in vitro translation products of cyclins A, B1, B2, C, and D1 (data not shown).

After a strong immune response developed, the antibodies were tested for specificity to cyclin E by immunoblots (Fig. 1A) and immunoprecipitations of metabolically labeled cells (Fig. 1B). For immunoblots, wholecell extracts were prepared from asynchronously growing ML-1 cells (a myeloid leukemia cell line) (lanes 1) and from ML-1 cells arrested at the $G_{1} / S$ boundary by a double thymidine block (lanes 2) (Rao and Johnson 1970). Figure 1A shows that the mouse polyclonal antiserum raised against cyclin $\mathrm{E}$ recognized a single polypeptide species migrating with a relative molecular mass of $\sim 51 \mathrm{kD}$. A band of this same size was also detected by use of an anti-cyclin $\mathrm{E}$ rabbit antiserum. The in vitro translation product of cyclin E migrated with a similar mobility (data not shown). The levels of this protein were elevated significantly in double thymidine-blocked cells (lanes 2), as has been observed in independent experiments by Dulic and colleagues (1992). The mouse antiserum failed to recognize any other proteins, indicating that there is no strong cross-reactivity with other denatured proteins, particularly with other cyclins. A duplicate blot probed with a cyclin A monoclonal antibody, BF683 (Faha et al. 1992a), showed similarly elevated levels of cyclin A in the drug-treated cells. This also served as a good control for the specificity of the cyclin $\mathrm{E}$ antibodies, as they failed to recognize cyclin A at this easily detectable level.

To test the ability of the antisera to recognize native cyclin E, we performed immunoprecipitations from de- 


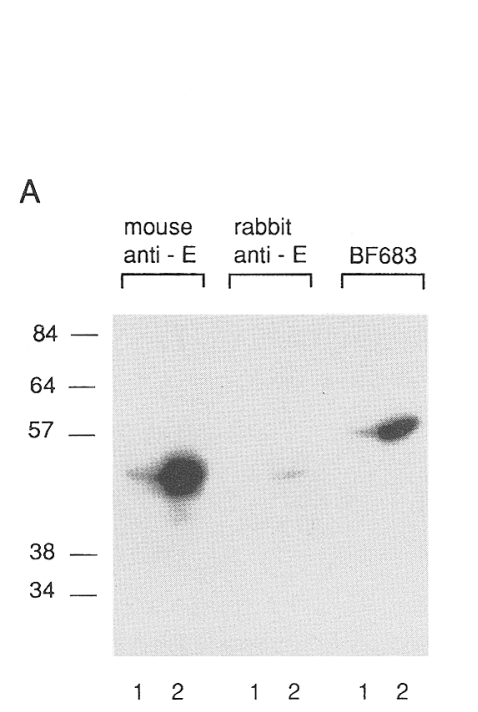

\section{B}

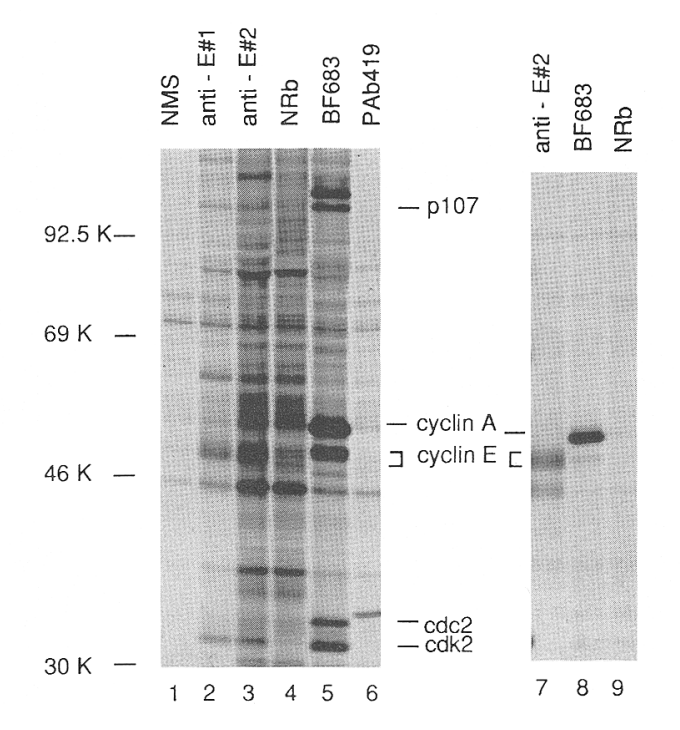

Figure 1. Characterization of antibodies raised against human cyclin E. $(A)$ Immunoblot analysis. Whole cell lysates were prepared, in SDS-PAGE sample buffer, from an asynchronous culture of ML-1 cells (lanes 1) and from ML-1 cells arrested by a double thymidine block (lanes 2). Equal amounts of protein were loaded per lane. The blots were probed with either a mouse anti-cyclin $\mathrm{E}$ antiserum or a rabbit anti-cyclin E antiserum. A parallel blot was probed with a cyclin A monoclonal antibody (BF683). HRP- labeled secondary antibodies were used, and antibody-antigen complexes were detected by chemiluminescence. Molecular mass markers (kD) are shown at left. (B) Immunoprecipitation analysis. ML-1 cells were treated with thymidine for $18 \mathrm{hr}$, and metabolically labeled with $\left[{ }^{35} \mathrm{~S}\right]$ methionine. Immunoprecipitations were performed on detergent lysates with two different mouse anti-cyclin $E$ antisera (1 in lane 2; 2 in lanes 3 and 7$)$, normal mouse serum (NMS; lane 1), normal rabbit serum (NRb; lanes 4 and 9), a cyclin A monoclonal antibody (BF683; lanes 5,8) and a monoclonal antibody against SV40 T antigen (PAb416) as a negative control (lane 6). In lanes 7-9, lysates were treated with $2 \%$ SDS and subsequently boiled to disrupt protein complexes before immunoprecipitation. (C) V8 partial proteolytic mapping of human cyclin E. An anti-cyclin E immunoprecipitation of ${ }^{35} \mathrm{~S} \mid$ methionine-labeled denatured cell lysate was separated on an $8 \%$ SDS-polyacrylamide gel, and the band corresponding to cyclin E was excised and treated with three concentrations of V8 protease from $S$. aureus. Cyclin E synthesized in vitro in rabbit reticulocyte lysate was treated in a similar fashion for comparison. $(D)$ Immunoprecipitation analysis of orthophosphate-labeled 293 cells (lane 1) using anti-ElA antibody (M73), and analysis of thymidine-blocked ML-1 cells (lane 2) using anti-cyclin E antisera.
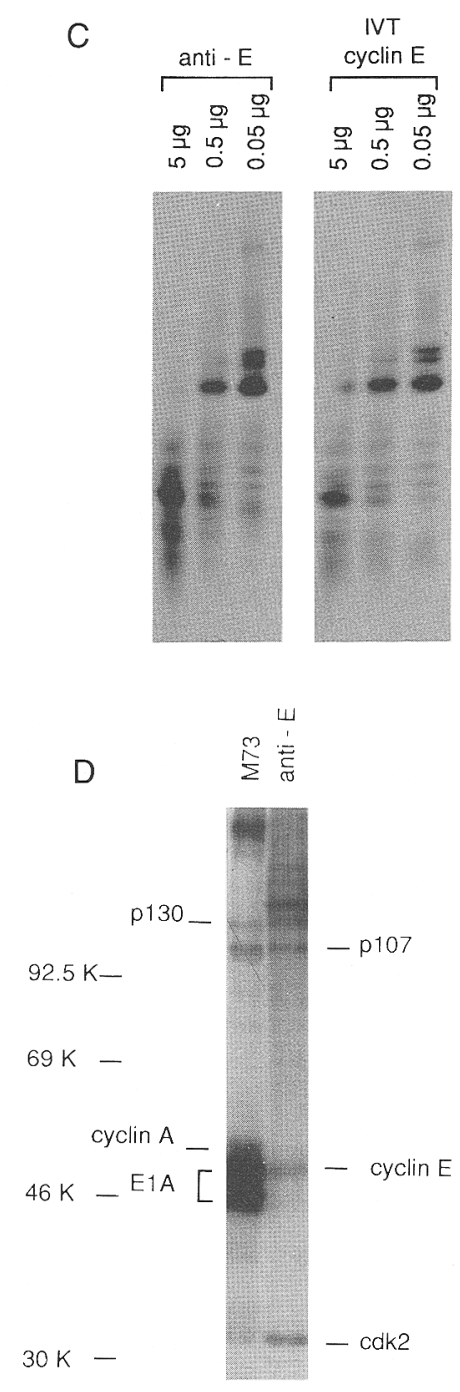

tergent lysates of metabolically labeled cells (Fig. 1B). Cyclin $\mathrm{E}$ antisera specifically precipitated a broad band of polypeptides migrating with apparent molecular masses of 48-51 kD (lanes 2,3). Given the low abundance of cyclin $E$ and its heterogeneous nature, a long exposure of the gel to film was required to visualize the putative cyclin E band clearly. At this exposure a number of other polypeptides that were precipitated with these antisera were also intensified. We therefore performed immunoprecipitations in parallel on denatured lysates (lanes 7-9) to discriminate between associated proteins and polypeptides with cross-reactive epitopes. Lane 7 shows that the cyclin $\mathrm{E}$ antiserum recognized only two polypeptides specifically: the broad $48-$ to $51-\mathrm{kD}$ species and a faster migrating $46-\mathrm{kD}$ species. To confirm the identity of the slower migating protein as cyclin E, we performed V8 protease partial proteolytic mapping on the protein excised from a SDS-polyacrylamide gel and compared the pattern of digestion with similarly treated cyclin E synthesized in vitro. Both gave identical patterns (Fig. 1C), confirming that this broad band was cyclin E. The identity of the additional $46-\mathrm{kD}$ polypeptide seen in lane 7 is not known but may be a degradation product of cyclin $\mathrm{E}$ resulting during the denaturation process. A protein migrating with similar but somewhat slower mobility to cyclin $\mathrm{E}$ was seen in anti-cyclin A immunoprecipitates (lane 5); this proved to be distinct from cyclin $\mathrm{E}$ by proteolytic mapping (data not shown). The appearance of a broad band suggested that cyclin $\mathrm{E}$ was post-translationally modified to produce variable migrating species. $\mathrm{Cy}-$ clin E immunoprecipitates performed on cells labeled with orthophosphate (Fig. 1D, lane 2) indicated that at least one of these forms was phosphorylated.

The cyclin E antibodies also coprecipitated a polypeptide of $\sim 33 \mathrm{kD}$. This band migrated with similar mobility to cdk2, as seen in an anti-cyclin A immunoprecipitation (Fig. 1B, lane 5) and in an anti-E1A immunoprecipitation (Fig. 1D, lane 1); immunochemical and proteolytic comparisons confirmed this identification (L.-H. Tsai, E. Harlow, and E. Lees, in prep.). Thus, cyclin 
E interacted with at least $\mathrm{cdk} 2$, although we cannot rule out the possibility that cyclin E associates with other, uncharacterized catalytic subunits. In addition, a protein of $\sim 107 \mathrm{kD}$ coprecipitated with the anti-cyclin $\mathrm{E}$ antisera (Fig. 1B, lanes 2,3; Fig. 1D, lane 2), which comigrated with p107 observed in anti-cyclin A immunoprecipitations (Fig. 1B, lane 5) and in anti-E1A immunoprecipitations from 293 cells (Fig. 1D, lane 1). The identification of this protein as p107 is discussed in a later section.

\section{E2F coprecipitates with cyclin $E$}

Both cyclins $\mathrm{A}$ and $\mathrm{E}$ are now known to bind to cdk2 (Tsai et al. 1991; Dulic et al. 1992; Faha et al. 1992b). The cyclin A/cdk2 complex has been described previously, and two assays have been described that characterize its activities. These include the temporal regulation of its kinase activity (Giordano et al. 1989; Pines and Hunter 1990; Pagano et al. 1992b; Rosenblatt et al. 1992) and the association with the transcription factor E2F (Cao et al. 1992; Devoto et al. 1992; Shirodkar et al. 1992). Both of these activities become detectable around the initiation of DNA synthesis. Recent work has shown that the cyclin E/cdk2 complex has a cell cycle-associated kinase activity that is activated in mid-to-late $G_{1}$, well before the initiation of DNA synthesis or the activation of cyclin A/cdk2 kinase activity and will be described elsewhere (Dulic et al. 1992; L.-H. Tsai, E. Harlow, and E. Lees, in prep.). In this study we were interested in investigating the involvement of other cyclins in the regulation of E2F activity.
To detect an association between cyclin $\mathrm{E}$ and E2F, cyclin $\mathrm{E}$ was immunoprecipitated from several different cell lines, ML-1, CEM (T lymphoblast), HL60 (myeloid leukemia), and MANCA (Burkitt's lymphoma), and immunocomplexes were tested for the presence of E2F. Figure $2 \mathrm{~A}$ shows that the cyclin $\mathrm{E}$ antiserum coprecipitated E2F activity in the cell lines tested, indicating that there was an association between cyclin E and E2F. Similar experiments with anti-pRB [XZ77 (Hu et al. 1991); lane 1] and anti-cyclin A [C160 (Giordano et al. 1989); lane 2] were included as positive controls for the presence of E2F. To rule out possible cross-reaction of our anti-cyclin $\mathrm{E}$ reagents with cyclin A, cell extracts were precleared of cyclin A using a monoclonal antibody against cyclin A (C160). As a negative control, lysates were precleared with PAb416 (Harlow et al. 1981), a monoclonal antibody against $\mathrm{SV} 40 \mathrm{~T}$ antigen. In the absence of cyclin A we detected similar levels of the E2F activity with the cyclin E antiserum as shown in Figure $2 B$ /cf. lanes 3 and 6). An association between cyclin $\mathrm{E}$ and E2F was supported further by the observation that a cyclin E GST fusion protein could bind E2F from cell lysates (data not shown).

The association of cyclin $E$ with E2F is regulated in a cell cycle-dependent manner

We then studied the profile of the association of cyclin $E$ with E2F through the cell cycle. Because it has been shown that cyclin E mRNA expression and associated kinase activity are cell cycle regulated with maximal
A

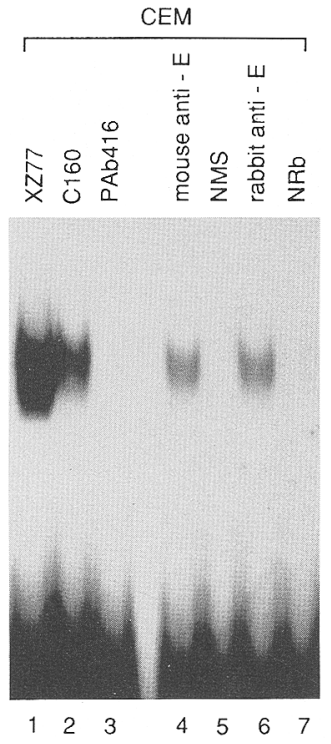

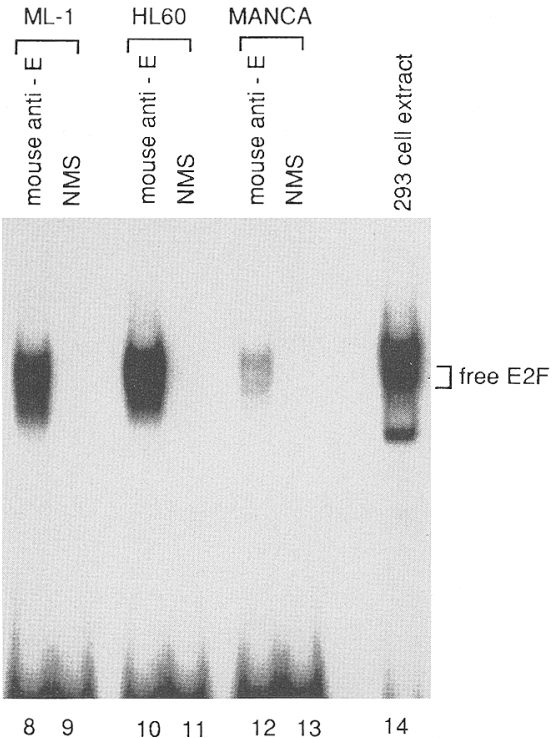

14

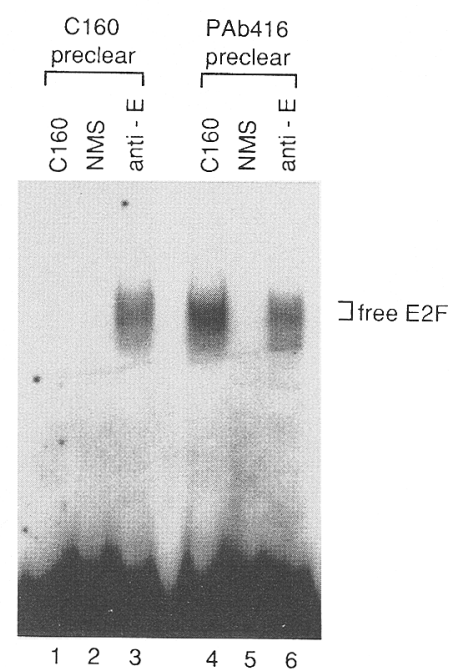

Figure 2. Association of cyclin $\mathrm{E}$ with transcription factor E2F in dividing cells. $(A)$ Cell extracts from a number of different cell lines were immunoprecipitated with the indicated antibodies. Monoclonal antibodies against pRB (XZ77; lane 1), cyclin A (C160; lane 2), and SV40 large T antigen (PAb416; lane 3) were included as controls. Immune complexes were treated with DOC, and the eluate was assayed for E2F activity by a gel retardation assay. A whole-cell extract from 293 cells served as a marker for E2F mobility. (B) Whole-cell extracts from ML-1 cells were precleared of cyclin A using an anti-cyclin A antibody (C160) cross-linked to beads. PAb416 cross-linked beads were used as a negative control. Immunoprecipitations were performed using antibodies as indicated. Immune complexes were disrupted with DOC and assayed for E2F activity as before. 
expression and activity at the $\mathrm{G}_{1} / \mathrm{S}$ boundary (Lew et al. 1991; Dulic et al. 1992; Tsai et al. 1992), we were interested to learn whether the association of cyclin $E$ and E2F was regulated in a similar fashion. To obtain cells that were enriched for a particular phase of the cell cycle, we tried two methods: (1) treatment of cells with drugs known to arrest at specific stages of the cell cycle, and (2) centrifugal elutriation to separate cells on the basis of cell size. Extracts were prepared from these cells, and cyclin $\mathrm{E}$ and cyclin A immunoprecipitations were tested for the presence of E2F as before. Figure 3A shows that cyclin $\mathrm{E}$ is associated with E2F in cells blocked in both late $G_{1}$ by mimosine, a plant amino acid analog (Lalande 1990 ), and in S phase by hydroxyurea. In contrast, the levels of cyclin A association were highest in cells arrested in $M$ phase by the microtubule inhibitory drug nocodazole (lane 12) and were markedly reduced in the earlier blocks. These experiments suggested that the timing of cyclin E association with E2F was different from that observed with cyclin $\mathrm{A}$, occurring earlier in the cell cycle as indicated from elevated levels in $G_{1}$-arrested cells.
Figure 3. Cell cycle analysis of E2F/cyclin complexes in drug-arrested ML-1 cells (A) and elutriated HL60 cells (B). (A) Whole-cell extracts were prepared from ML-1 cells, treated with drugs, where indicated. Immunoprecipitations were performed using mouse anti-cyclin $\mathrm{E}$ antiserum (anti-E), normal mouse serum (NMS), and a cyclin A monoclonal antibody (C160; anti-A). Immune complexes were disrupted with DOC and assayed for E2F activity. A whole-cell extract from 293 cells served as a marker for E2F mobility. The DNA content of cells from each treatment was determined by FACS analysis to give a measure of the relative percentages of $\mathrm{G}_{1}, \mathrm{~S}, \mathrm{G}_{2}$ cells in each sample (bottom). (B) HL60 cells were elutriated, and wholecell extracts were prepared from various fractions (2-9). Immunoprecipitations were performed using antibodies as indicated and analyzed as described in $A$.

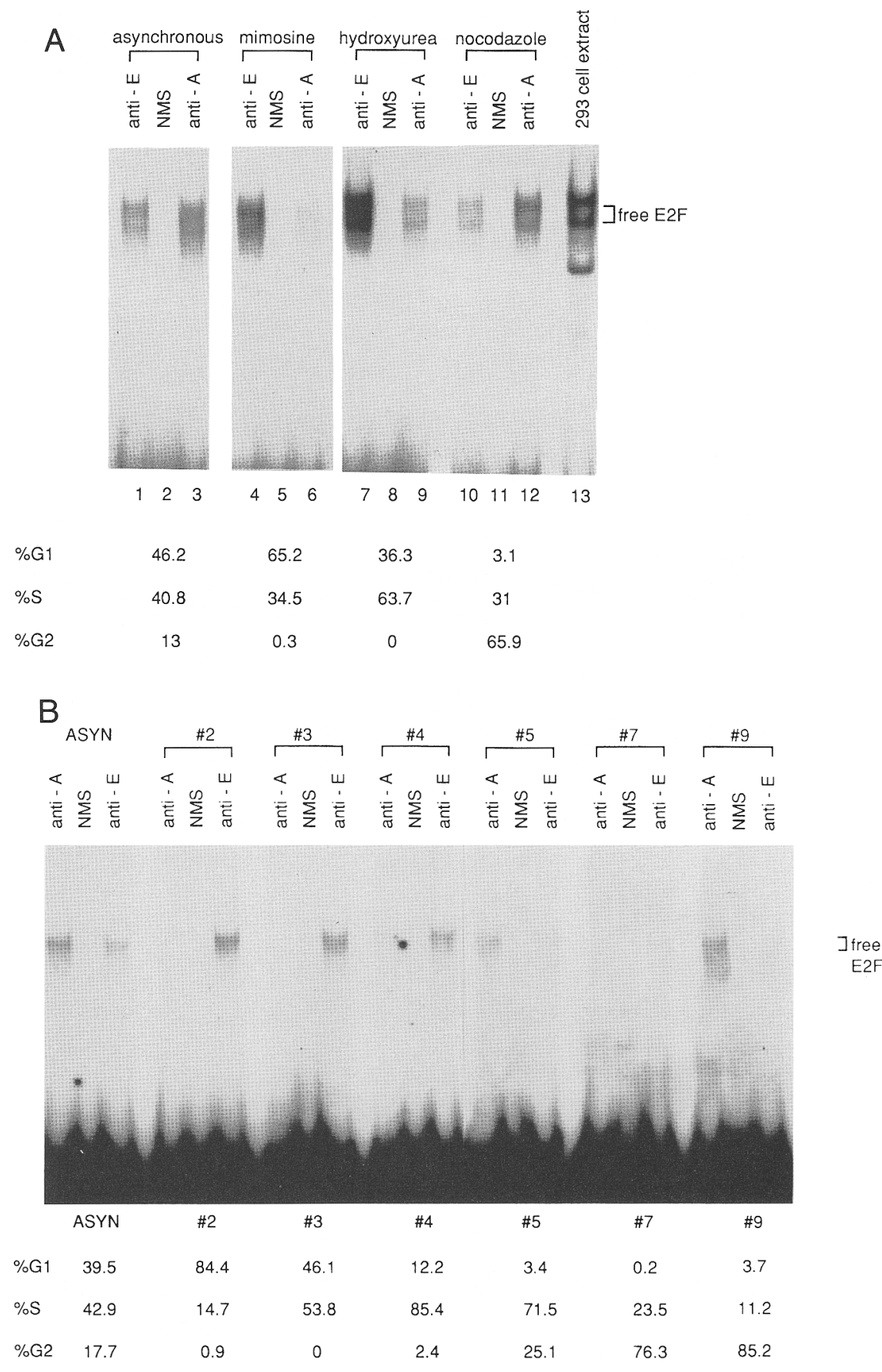


Previously, we have observed that some drugs, thymidine for example, caused artificially high levels of cyclins to accumulate in the treated cells. Therefore, we used a second method of synchrony, centrifugal elutriation, to confirm these observations as shown in Figure 3B. Several fractions were collected, and extracts were prepared, and subsequently tested for the presence of E2F as before. In earlier fractions containing $85 \% \mathrm{G}_{1}$ cells (fraction 2), only cyclin $\mathrm{E}$ was found to be associated with E2F. The levels of cyclin E/E2F complexes decreased in later fractions. In contrast, E2F in cyclin A immunoprecipitations only appeared as extracts became enriched for S-phase cells, being first detectable in fractions containing $85 \%$ S-phase cells (fraction 4). Levels of cyclin A-associated E2F activity continued to increase for a further two fractions and then disappeared by fraction $7\left(76 \% \mathrm{G}_{2}\right.$ cells). We were surprised to see the reappearance of the cyclin A-associated E2F in the last fraction (9). This pattern has been repeated in two other elutriations (data not shown).

\section{Cyclin E associates with $p 107$ and cdk2 in vivo}

Association of E2F with both the product of the retinoblastoma gene product $(\mathrm{pRB})$ and a structurally related protein, p107 (Ewen et al. 1991), have been described previously (Bagchi et al. 1991; Bandara and La Thangue 1991; Chellappan et al. 1991; Chittenden et al. 1991; Raychaudhuri et al. 1991; Cao et al. 1992; Shirodkar et al. 1992). We were therefore interested to learn whether either of these two proteins was present in the cyclin E/E2F complex. As mentioned earlier immunoprecipitations of cyclin $\mathrm{E}$ contained a $107-\mathrm{kD}$ protein that comigrated with p107 coprecipitated with anti-cyclin A antibodies (Fig. 1B; cf. lanes 2 and 3 with lane 5 ) and with the anti-E1A monoclonal antibody M73 (Fig. 1D) (Harlow et al. 1985). Proteolytic mapping of these 107-kD species showed that they were indistinguishable, thus confirming the identity of the cyclin E-associated protein as p107 (Fig. 4A). We have also been able to detect cyclin $\mathrm{E}$ in anti-p107 immunoprecipitations (N. Dyson and E. Lees, unpubl.) providing further evidence for the complex, as detection is possible using reagents toward either component. Interestingly, p107 also appears to be a substrate for a cyclin E-associated kinase (Fig. 4B), showing that p107 could be phosphorylated in an in vitro kinase assay performed on a cyclin $\mathrm{E}$ immunoprecipitation. Immunoprecipitates of cyclin A (BF683) and E1A (M73) were included as controls because both are known to contain kinase activity that phosphorylates p107 (Herrmann et al. 1991; Faha et al. 1992a).

Using gel retardation assays, we were able to show the presence of p107 in the cyclin E/E2F complex as shown in Figure $5 \mathrm{~B}$. Visualization of the cyclin E/E2F complex by gel retardation proved problematic. It was first necessary to use $G_{1}$-enriched fractions from an HL60 elutriation to observe cyclin $\mathrm{E}$ complexes. In addition, the anticyclin $\mathrm{E}$ antiserum had to be diluted to obtain a supershifted complex that entered the gel rather than aggregating in the wells. Under these conditions we were

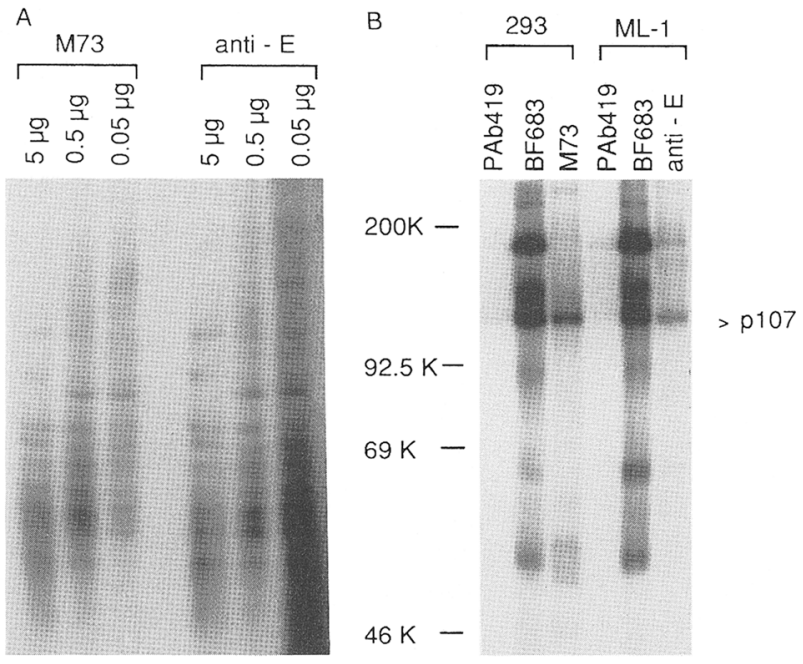

Figure 4. Cyclin E is associated with p107 in vivo. $(A)$ V8 partial proteolytic mapping of pl07. $\left[{ }^{35} \mathrm{~S}\right]$ Methionine-labeled 293 cells were immunoprecipitated with an E1A monoclonal antibody (M73). The p107 polypeptide coprecipitating with E1A was excised together with a comigrating band observed in cyclin $\mathrm{E}$ immunoprecipitations from metabolically labeled ML-1 cells. V8 partial proteolysis of the two proteins was performed, and the digested polypeptides were resolved on a $15 \%$ SDS-polyacrylamide gel. Three dilutions of the protease were used as indicated. $(B)$ In vitro kinase assays performed on immunoprecipitations, using either 293 cells or ML-1 cells with antibodies, as indicated.

able to detect a complex that was supershifted with anticyclin E antisera (Fig. 5A, lanes 3,5$)$ and that migrated slightly slower than the cyclin A-supershifted complex (Fig. 5A, lanes 6,8). The anti-cyclin E antisera could be specifically blocked with the cyclin E GST fusion protein but not by cyclin A GST fusion protein. We were surprised that neither the p107 nor the pRB-containing complexes were depleted by this supershift with cyclin E antibodies. However, we were able to show the presence of p107 in the cyclin E/E2F complex by virtue of the ability of an anti-p107 polyclonal antibody to further retard the anti-cyclin E-supershifted complex (Fig. 5B, lanes 4,5 ). The cyclin E-containing complexes were unaffected by the addition of control serum or tissue culture supernatant. The inability to appreciably deplete the p107 complex itself, with anti-cyclin E antisera, suggested that we were only detecting a very small fraction of the p107/E2F complexes associated with cyclin E, using this type of assay. We believe that this a result of the failure of the anti-cyclin $\mathrm{E}$ antisera to perform well in gel retardations, with the antisera only being able to shift a small percentage of total cyclin E complexes. The comparatively easy detection of cyclin $\mathrm{E}$ association with E2F by immunoprecipitation suggested that the levels of $\mathrm{cy}$ clin E/E2F complexes were significant. We are currently generating monoclonal antibodies against cyclin $E$ that will perform better in gel retardation assays. With such reagents it should be possible to obtain a more reliable 


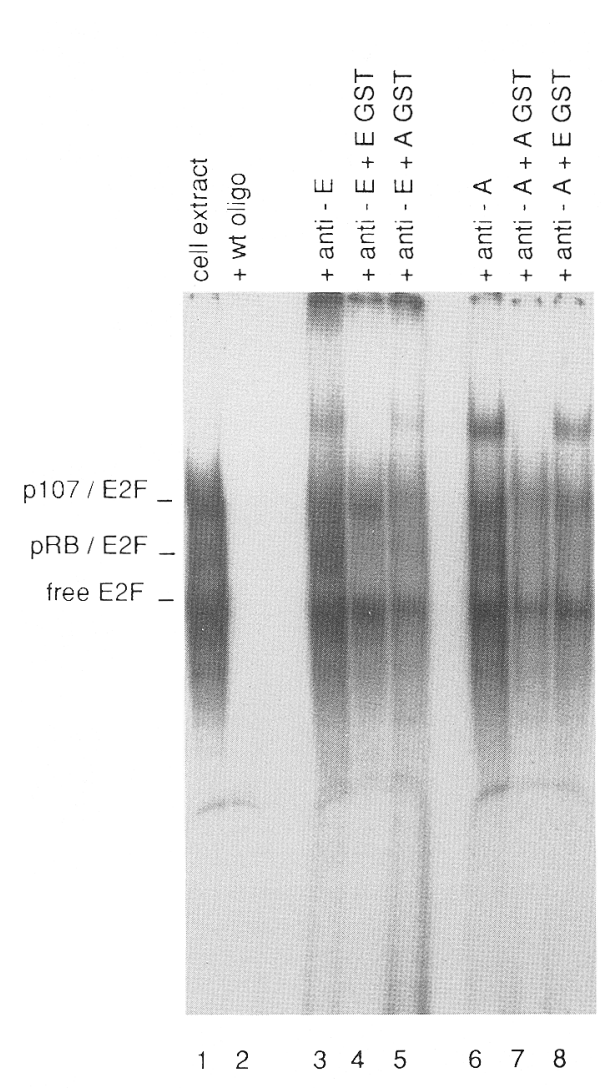

A
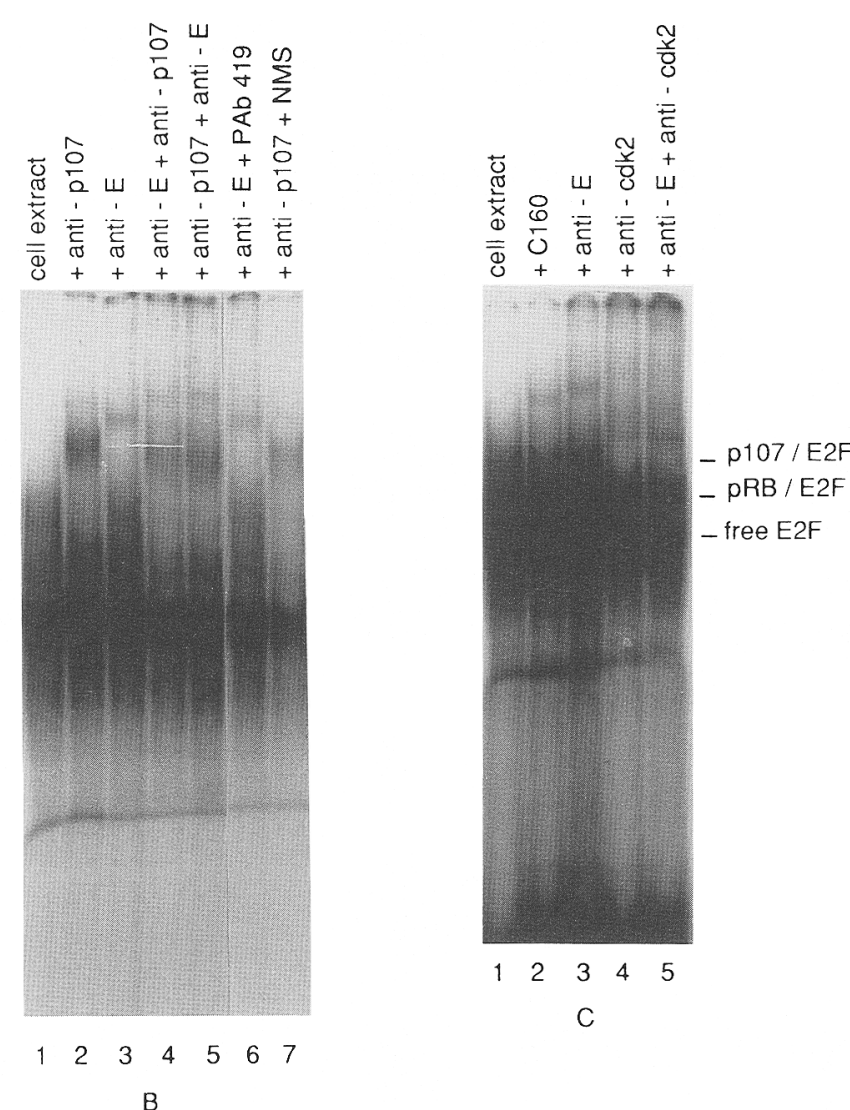

Figure 5. Detection of p107 and cdk2 in the cyclin E/E2F complex. Shown is a gel shift analysis of E2F complexes in $\mathrm{G}_{1}$-enriched elutriation fraction of HL60 cells. Gel shift reactions were incubated with the indicated antibodies. A $1: 5$ dilution of the cyclin E antiserum was used; $1 \mu \mathrm{l}$ of antibody was used in all other incubations. (A) Antibodies were blocked by preincubation with GST fusion proteins as indicated. $(B, C)$ For double antibody reactions, one was added $5 \mathrm{~min}$ before the addition of the other in the order stated. The complexes were separated from unbound probe on a $4 \%$ polyacrylamide gel. Free probe was run off the bottom of the gel to help resolve the retarded complexes.

estimate of relative amounts of cyclin E/E2F complexes as compared with other $G_{1}$ material. The cyclin E-containing complex was not completely shifted with the p107 antiserum (Fig. 5B, lanes 4,5), suggesting that cyclin $\mathrm{E}$ may be associated with other E2F complexes.

In similar experiments we investigated the possible presence of a kinase subunit in the cyclin E/E2F complex by looking at the ability of several anti-cdk reagents to alter the cyclin E supershift. Using cdk2-specific antisera (Tsai et al. 1991) we were able to abolish the cyclin E supershift as shown in Figure 5C (lane 5), whereas other antibodies recognizing other cdk-related enzymes had no effect (data not shown). We have additionally been able to show that immunoprecipitations of cyclin E contain $\mathrm{cdk} 2$, as shown in Figure 1B. This association has been characterized and will be described elsewhere (Dulic et al. 1992; L.-H. Tsai, E. Harlow, and E. Lees, in prep.). From these data we conclude that cyclin E/E2F complexes contain both p107 and cdk2.

We have performed a number of experiments to investigate the presence of $\mathrm{pRB}$ in these cyclin $\mathrm{E}$ complexes. We have tested several anti-pRB antibodies for their ability to alter the mobility of the cyclin $\mathrm{E}$ complex in a gel retardation assay, but none had a detectable effect /data not shown). In addition, cyclin $\mathrm{E}$ immunoprecipitations from two cell lines, WERI-1 and SAOS-2, which carry defective alleles of the RB-1 gene and therefore cannot produce functional pRB protein, contained substantial levels of E2F activity suggesting that the cyclin E/E2F association is not dependent on the presence of $\mathrm{pRB}$ /data not shown). Immunoprecipitations and Western blot analysis, with the reagents available, also failed to identify an association between cyclin $\mathrm{E}$ and $\mathrm{pRb}$. We cannot rule out the possibility that cyclin $\mathrm{E} / \mathrm{Rb} / \mathrm{E} 2 \mathrm{~F}$ complexes might exist in cell lines carrying wild-type $\mathrm{Rb}$ protein; however, if such complexes exist, we have been unable to detect them.

\section{p107 association with E2F through the cell cycle}

The presence of cyclin E/p107/E2F complexes in $G_{1}$ was surprising given previous models of $\mathrm{p} 107 / \mathrm{E} 2 \mathrm{~F}$ as an S-phase complex (Cao et al. 1992; Shirodkar et al. 1992). We were therefore keen to learn how the levels of p107 association with E2F changed as a function of cell cycle progression, in comparison to the fluctuations that we 
had observed with cyclin A and cyclin E. Immunoprecipitations were performed on elutriated HL60 cells by use of either a polyclonal antiserum against p107 (Cao et al. 1992) or anti-cyclin E and anti-cyclin A reagents as before. Figure 6 shows that p107 was found associated with E2F throughout the cell cycle, albeit at varying levels. Levels were high in the earliest fractions reminiscent of cyclin $\mathrm{E}$, peaking in $\mathrm{S}$ phase where levels of cyclin $\mathrm{E} / \mathrm{E} 2 \mathrm{~F}$ were still detectable but where cyclin A/E2F was most abundant, and decreased through $G_{2}$ with an increase in the last fraction as is seen with cyclin A. Thus, comparing the profile of p107 to cyclin E and cyclin A, it appears that $\mathrm{p} 107$ is a composite of the pattern seen with the two cyclins.

\section{Discussion}

Cyclin E association with E2F during $G_{1}$

E2F is a critical transcription factor that is needed for the expression of at least one protein (DHFR) essential for DNA replication (Blake and Azizkhan 1989). The appearance of E2F-binding sites in the promoters of other genes

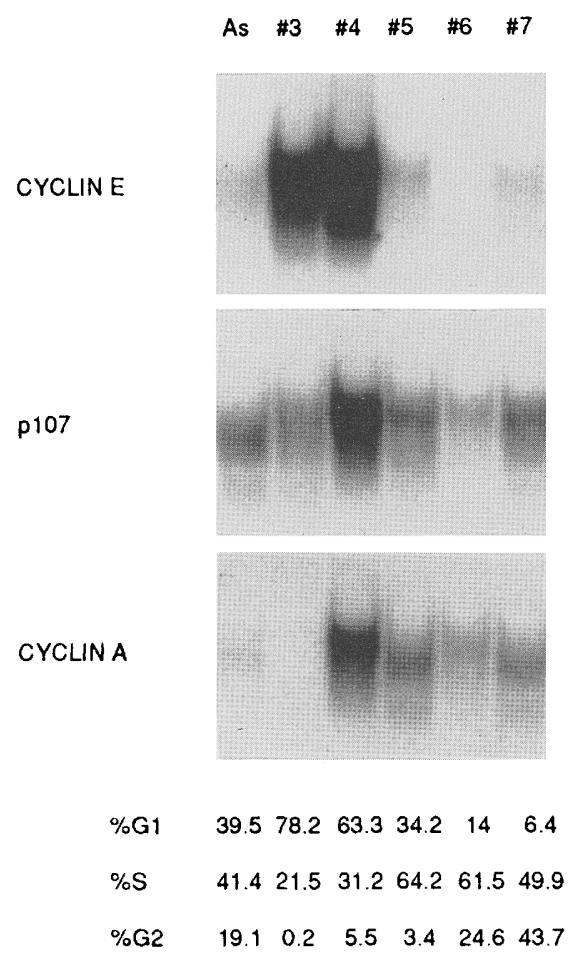

Figure 6. Cell cycle analysis of p107 complexes in HL60 cells. Whole-cell extracts were prepared from elutriation fractions of HL60 cells. Immunoprecipitations were performed using a mouse anti-cyclin E antiserum, a mouse anti-p107 antiserum (Cao et al. 1992), and a cyclin A monoclonal antibody (C160). Immune complexes were disrupted with DOC and assayed for E2F activity. The DNA content of cells from each fraction was determined by FACS analysis to give a measure of the relative percentages of $G_{1}, S$, and $G_{2}$ cells in each fraction (bottom). that encode proteins needed for DNA synthesis suggests that the requirement for E2F activation may be a characteristic of many such genes. Consequently, the regulation of E2F activity may help to control the timing of $S$ phase by providing temporal transcriptional regulation. How this regulation might occur is still poorly understood; however, the physical association with cyclin/kinase complexes provides a possible mechanism. This type of control was first suggested by the demonstration of a cyclin A/cdk2/p107/E2F complex during S phase (Mudryi et al. 1991; Cao et al. 1992; Devoto et al. 1992; Pagano et al. 1992a; Shirodkar et al. 1992). This work raised the possibility that other cyclin/kinase complexes might function in the regulation of E2F during other stages of the cell cycle. Cyclin E was a good candidate for performing such a role in $G_{1}$, given its pattern of expression (Lew et al. 1991) and kinase activity (Dulic et al. 1992; L.-H. Tsai, E. Harlow, and E. Lees, in prep.), both peaking at the $G_{1} / S$ boundary.

Using cyclin E-specific reagents, we have shown that cyclin $E$ associates with the transcription factor E2F during the $G_{1}$ phase of the cell cycle, suggesting a functional role for this cyclin before DNA synthesis. The timing of the appearance of the cyclin E/E2F complex is in marked contrast to the later appearance of the cyclin A/E2F complex (Mudryj et al. 1991; Pagano et al. 1992a; Shirodkar et al. 1992). Given this difference, it was therefore a surprise to learn that the other components of the two cyclin/E2F complexes were the same, namely p107 and $c d k 2$. It is thus apparent that the temporal appearance of the two complexes must be at least one of the keys in determining their potential roles.

The difference in timing of cyclin $\mathrm{A}$ and cyclin $\mathrm{E}$ association with E2F correlates well with the appearance of the respective proteins through the cell cycle and, interestingly, with the appearance of associated histone $\mathrm{H} 1$ kinase activity (Dulic et al. 1992; L.-H. Tsai, E. Harlow, and $\mathrm{E}$. Lees, in prep.). It is therefore attractive to speculate that these kinases are playing an active role in the regulation of $\mathrm{E} 2 \mathrm{~F}$ activity by phosphorylation of components of the complexes such as pRB, p107, or even E2F itself. p107 appears to be a substrate for both cyclin A and cyclin $\mathrm{E}$, at least in vitro.

\section{New models for E2F regulation}

The first models for the roles of $\mathrm{pRB}$ and p107 in E2F regulation predicted distinct functions for $\mathrm{pRB}$ and $\mathrm{p} 107$, during $G_{1}$ and $S$ phase, respectively, both acting in the regulation of a single E2F activity. Clearly, our experiments as well as those of others (e.g., Shirodkar et al. 1992) now imply a more complicated scenario. Our observations define two complexes of p107/E2F that are found at different points in the cell cycle. At least one other complex containing $\mathrm{pRB}$ is also present, but other complexes may exist as well. A possible example of another is the $G_{1}$ complex, tentatively designated as $X$, described by Shirodkar and colleagues (1992). The demonstration of multiple E2F complexes raises interesting 
questions about their respective roles. Three general models must be considered. First, perhaps these complexes regulate the same set of promoters, and the various complexes are responsible for a complicated series of positive and/or negative regulatory decisions that are temporally controlled. Alternatively, the different complexes may regulate E2F in a similar fashion but may direct E2F to different subsets of genes. Finally, these different complexes may identify a series of E2F-like transcription factors that might target different genes or the same genes at different times. Both of the later two models are attractive given the large number of genes that contain E2F sites, and they suggest an elegant scheme for regulation of a diverse set of genes using a relatively small set of players.

It would seem that the p107/E2F complex will be a particularly good system to begin the further analysis of how these various complexes are regulated. The demonstration of the $G_{1}$-phase association with cyclin $E / c d k 2$ and the S-phase association with cyclin A/cdk2 should provide a useful comparison to study these complexes. The next important step will be to investigate the ability of the cyclin $\mathrm{E}$ and cyclin A complexes to differentially regulate genes containing E2F sites. The cyclins apparently provide an important timing control dictated by the different phases of the cell cycle.

\section{Materials and methods}

\section{Antisera}

A full-length cyclin E cDNA was cloned into the expression vector pGEX-2T (Pharmacia). This construct was used to transform Escherichia coli XA90 cells. The transformed cells were grown to $\mathrm{OD}_{550}=0.6$ and induced with $0.1 \mathrm{~mm}$ IPTG to produce a fusion protein with GST. The fusion protein was purified as described previously (Smith and Johnson 1988). BALB/c mice received repeated injections of 20-50 $\mu \mathrm{g}$ of purified protein. Preparation of rabbit polyclonal cyclin E antisera is described elsewhere (Dulic et al. 1992). The mouse polyclonal cdk2-specific antiserum was kindly provided by L.-H. Tsai (Tsai et al. 1991), and the polyclonal p107 antibodies were provided by S. Dembski (Cao et al. 1992). Monoclonal antibodies used in these studies have all been described previously: BF683 (Faha et al. 1992a); C160 (Giordano et al. 1989); XZ77 (Hu et al. 1991); PAb419 and PAb416 (Harlow et al. 1981). Covalent cross-linking of antibodies to protein A-Sepharose beads was performed as described previously (Harlow and Lane 1988).

\section{Cell lines}

ML-1, CEM, HL60, and WERI-1 cells were grown as suspension cultures in Dulbecco's modified Eagle medium (DMEM) supplemented with $10 \%$ fetal bovine serum. SAOS- 2 cells and 293 cells were grown as monolayers in DMEM supplemented with $10 \%$ calf serum.

\section{Synchronization and centrifugal elutriation}

ML-1 cells were synchronized by use of a double thymidine block (Rao and Johnson 1970). Cells were treated with $2 \mathrm{~mm}$ thymidine for $18 \mathrm{hr}$ and released into fresh media containing $10 \%$ FBS for $10 \mathrm{hr}$, and $2 \mathrm{~mm}$ thymidine was added for an ad- ditional $18 \mathrm{hr}$. Cells were harvested by centrifugation (1000 $\mathrm{rpm} / 5 \mathrm{~min}$ ) and washed once in cold PBS, and the pellets were frozen at $-70^{\circ} \mathrm{C}$ until use. Other $G_{1}$ arrests were achieved by treating asynchronously growing ML-1 cells with hydroxyurea at a final concentration of $5 \mu \mathrm{g} / \mathrm{ml}$ for $18 \mathrm{hr}$ or by mimosine at $2 \mathrm{~mm}$ for $18 \mathrm{hr}$. Nocodazole was used at a final concentration of $50 \mathrm{ng} / \mathrm{ml}$ for $18 \mathrm{hr}$ to arrest cells in $\mathrm{G}_{2}$. For fractionation of cells by centrifugal elutriation, HL60 cells were grown in suspension at a density of $1 \times 10^{6}$ cells $/ \mathrm{ml}$ in $10 \%$ heat-inactivated FBS (HIFBS). Cells were split the day before elutriation into $20 \%$ HIFBS, to give a 4 -liter culture at $5 \times 10^{5}$ cells $/ \mathrm{ml}$. Approximately $2 \times 10^{9}$ cells in elutriation buffer (Giordano et al. 1989) were loaded onto a Beckman JE5.0 elutriator rotor spinning at $1750 \mathrm{rpm}$ at a rate of $130 \mathrm{ml} / \mathrm{min}$. The centrifugal speed was then adjusted to $1550 \mathrm{rpm}$, and fractions were collected as the flow rate was increased by increments of $20 \mathrm{ml} / \mathrm{min}$. Cell pellets were frozen at $-70^{\circ} \mathrm{C}$. Samples were taken to be analyzed for DNA content after staining with propidium iodide by FACS.

\section{Western blotting}

Cells were lysed in SDS-sample buffer, sonicated, and heated to $90^{\circ} \mathrm{C}$ for $10 \mathrm{~min}$. The equivalent of $1.0 A_{280}$ was separated on a $10 \%$ SDS-polyacrylamide gel. Following electrophoresis, proteins were transferred to Immobilon membranes (Millipore) at $30 \mathrm{~V}$ for $3 \mathrm{hr}$ at $4^{\circ} \mathrm{C}$, using standard techniques (Sambrook et al. 1989). The immunoblotting was performed as described (Dulic et al. 1992). Primary antibodies were used at $1: 2000$ dilution for polyclonal antisera and $1: 4$ for monoclonal antibody supernatants. Secondary antibodies were either peroxidase-conjugated goat anti-rabbit or anti-mouse immunoglobulins (Cappel; used at 1:5000 dilution). The detection system used was chemiluminescence (ECL; Amersham).

\section{Immunoprecipitations}

Immunoprecipitations were performed on cells lysed with buffer containing $250 \mathrm{~mm} \mathrm{NaCl}, 50 \mathrm{mM}$ HEPES ( $\mathrm{pH} 7.0$ ), and $0.1 \%$ NP-40, as described previously (Harlow et al. 1985) . Lysates were denatured by the addition of SDS to a final concentration of $2 \%$ followed by boiling for $10 \mathrm{~min}$. The denatured sample was diluted 20 -fold before the addition of antibody. Immunoprecipitations performed on cells metabolically labeled with $\left[{ }^{35} \mathrm{~S}\right]$ methionine were analyzed by separation of immune complexes by SDS-PAGE on $8 \%$ gels at $50 \mathrm{~mA}$ and visualized by fluorography.

\section{Proteolytic mapping with V8 protease}

Mapping with V8 protease from Staphylococcus aureus was performed as described previously (Harlow and Lane 1988).

\section{Kinase assays}

Immunoprecipitations were performed on unlabeled cell lysates, and complexes were adsorbed onto protein A-Sepharose beads and washed three times in lysis buffer and once in kinase buffer containing $50 \mathrm{mM}$ Tris ( $\mathrm{pH} 7.4), 10 \mathrm{mM} \mathrm{MgCl}$, and $1 \mathrm{mM}$ DTT. Beads were resuspended in $50 \mu \mathrm{l}$ of kinase buffer containing $1 \mu \mathrm{M}$ ATP and $5 \mu \mathrm{Ci}$ of $\left[\gamma^{-32} \mathrm{P}\right] \mathrm{ATP}$. Reactions were incubated at room temperature for $30 \mathrm{~min}$, stopped by the addition of $2 \times$ sample buffer, and resolved on a $10 \%$ polyacrylamide gel. 


\section{Preparation of whole-cell extracts}

Whole-cell extracts were prepared as described previously (Raychaudhuri et al. 1987). Frozen cell pellets (washed in PBS) were thawed on ice and resuspended in 1.5 volumes of lysis buffer containing $10 \mathrm{~mm}$ HEPES (pH 7.6), $5 \mathrm{~mm} \mathrm{KCl}, 1.5 \mathrm{~mm} \mathrm{MgCl}$, $0.5 \mathrm{~mm} \mathrm{NaF}, 1 \mathrm{~mm}$ DTT, $0.5 \mathrm{mM}$ PMSF, and $0.5 \mathrm{mM} \mathrm{Na}_{3} \mathrm{VO}_{4}$. After $15 \mathrm{~min}$ of incubation on ice, 1.66 volume of extraction buffer [20 mM HEPES ( $\mathrm{pH} 7.6$ ), $1.6 \mathrm{M} \mathrm{KCl}, 20 \%$ glycerol, $0.1 \mathrm{mM}$ EDTA, 0.5 mM NaF, $1 \mathrm{~mm}$ DTT, 0.5 mM PMSF, $\left.0.5 \mathrm{~mm} \mathrm{Na}_{3} \mathrm{VO}_{4}\right]$ was added, and extracts were rocked at $4^{\circ} \mathrm{C}$ for $45 \mathrm{~min}$. Extracts were centrifuged at $100,000 \mathrm{~g}$ for $45 \mathrm{~min}$, and the supernatants were then taken and dialyzed for $1.5 \mathrm{hr}$ at $4^{\circ} \mathrm{C}$ against $20 \mathrm{~mm}$ HEPES ( $\mathrm{pH} 7.6$ ), $50 \mathrm{~mm} \mathrm{KCl}, 10 \%$ glycerol, $0.1 \mathrm{~mm}$ EDTA, 0.5 $\mathrm{mM} \mathrm{NaF}, 1 \mathrm{mM}$ DTT, $0.5 \mathrm{~mm}$ PMSF, and $0.5 \mathrm{mM} \mathrm{Na}_{3} \mathrm{VO}_{4}$. Precipitates formed during the dialysis were removed by centrifugation at $10,000 \mathrm{~g}$ for $5 \mathrm{~min}$. Protein concentrations were determined by the Bradford method (Bio-Rad), and extracts were aliquoted and stored at $-70^{\circ} \mathrm{C}$.

\section{Deoxycholate release from immune complexes}

Immunoprecipitations were performed using $300 \mu \mathrm{g}$ of wholecell extract, in a buffer containing 20 mM HEPES (pH 7.4), 40 $\mathrm{mm} \mathrm{KCl}, 1 \mathrm{~mm} \mathrm{MgCl} 2$, and $0.1 \mathrm{~mm}$ EDTA to which $3 \mathrm{mg} / \mathrm{ml}$ of BSA had been added. After adsorption onto protein A-Sepharose beads, the immune complexes were washed four times with the above buffer. Complexes were disrupted by incubation with $0.8 \%$ sodium deoxycholate (DOC) for $10 \mathrm{~min}$ on ice (Baeuerle and Baltimore 1988). NP-40 was added to a final concentration of $1.5 \%$, and samples were then analyzed by gel retardation with a ${ }^{32}$ P-labeled E2F oligonucleotide probe.

\section{Gel retardation assays}

Gel retardation assays were performed as described previously (Yee et al. 1987). Cell extract $(5-10 \mu \mathrm{g}$ ) was used directly in a binding buffer containing $20 \mathrm{~mm}$ HEPES (pH 7.4), $40 \mathrm{~mm} \mathrm{KCl}, 1$ $\mathrm{mM} \mathrm{MgCl}_{2}, 0.1 \mathrm{mM}$ EDTA, and $0.1 \% \mathrm{NP}-40$, to which was added $0.5 \mathrm{ng}$ of ${ }^{32} \mathrm{P}$-labeled probe and $1 \mu \mathrm{g}$ of sonicated salmon sperm DNA. For antibody shifts, gel shift reactions were incubated with $1 \mu \mathrm{l}$ of antibody for $10 \mathrm{~min}$ before probe addition. For blocking, antibodies were preincubated on ice for $30 \mathrm{~min}$ with $10 \mu \mathrm{g}$ of fusion protein. The reaction products were separated on a $4 \%$ polyacrylamide gel run in $0.25 \times \mathrm{TBE}$ at $4^{\circ} \mathrm{C}$ at $180 \mathrm{~V}$. The gel was then dried and exposed to film.

\section{Oligonucleotides}

The sequences of the oligonucleotides (Cao et al. 1992) are as follows:

\section{E2F: ATTTAAGTTTCGCGCCCTTTCTCAA MT: ATTTAAGTTTCGATCCCTTTCTCAA}

\section{Acknowledgments}

We thank A. Fattaey, K. Helin, and N. Dyson for their help and suggestions throughout the project and for critical reading of this manuscript; S. Dembski and L.-H. Tsai for antibodies; L. Cao for his help in setting up the E2F gel retardation system; and members of the Harlow laboratory for helpful comments and reading of the manuscript. E. Lees was funded by a longterm fellowship from Human Frontiers of Science Program Organisation, and V. Dulic received a fellowship (823A-28422) from the Swiss National Fund. This work was supported by U.S. Public Health Services grant CA55339 to E.H. and GM38328 and GM 46006 to S.I.R.. E.H. is supported as an American Cancer Society Research Professor.

The publication costs of this article were defrayed in part by payment of page charges. This article must therefore be hereby marked "advertisement" in accordance with 18 USC section 1734 solely to indicate this fact.

\section{References}

Baeuerle, P.A. and D. Baltimore. 1988. Activation of DNA-binding activity in an apparently cytoplasmic precursor of the NF-kB transcription factor. Cell 53: 211-217.

Bagchi, S., R. Weinmann, and P. Raychaudhuri. 1991. The retinoblastoma protein copurifies with E2F-I, an E1A-regulated inhibitor of the transcription factor E2F. Cell 65: 1063-1072.

Bandara, L.R. and N.B. La Thangue. 1991. Adenovirus Ela prevents the retinoblastoma gene product from complexing with a cellular transcription factor. Nature 351: 494-497.

Bandara, L.R., J.P. Adamczewski, T. Hunt, and N. La Thangue. 1991. Cyclin A and the retinoblastoma gene product complex with a common transcription factor. Nature 352: 249251.

Blake, M.C. and J.C. Azizkhan. 1989. Transcription factor E2F is required for efficient expression of the hamster dihydrofolate reductase gene in vitro and in vivo. Mol. Cell. Biol. 9: 4994 5002.

Booher, R.N., C.E. Alfa, J.S. Hyams, and D.H. Beach. 1989. The fission yeast $\mathrm{cdc} 2 / \mathrm{cdc} 13 / \mathrm{sucl}$ protein kinase: Regulation of catalytic activity and nuclear localization. Cell 58: 485-497.

Cao, L., B. Faha, M. Dembski, L.-H. Tsai, E. Harlow, and N. Dyson. 1992. Independent binding of the retinoblastoma protein and p107 to the transcription factor E2F. Nature 355: $176-179$.

Chellappan, S., S. Hiebert, M. Mudryi, J. Horowitz, and J. Nevins. 1991. The E2F transcription factor is a cellular target for the RB protein. Cell 65: 1053-1061.

Chittenden, T., D. Livingston, and W. Kaelin. 1991. The T/E1Abinding domain of the retinoblastoma product can interact selectively with a sequence-specific DNA-binding protein. Cell 65: 1073-1082.

Cross, F.R. 1988. DAF1, a mutant gene affecting size control, pheromone arrest, and cell cycle kinetics of Saccharomyces cerevisiae. Mol. Cell. Biol. 8: 4675-4684.

Devoto, S.H., M. Mudryi, J. Pines, T. Hunter, and J.R. Nevins. 1992. A cyclin A- specific protein kinase complex possesses sequence-specific DNA binding activity: $\mathrm{p} 33 \mathrm{cdk} 2$ is a component of the E2F-cyclin A complex. Cell 68: 167-176.

Draetta, G., F. Luca, J. Westendorf, L. Brizuela, J. Ruderman, and D. Beach. 1989. Cdc2 protein kinase is complexed with both cyclin A and B: Evidence for proteolytic inactivation of MPF. Cell 56: 829-838.

Dulic, V., E. Lees, and S.I. Reed. 1992. Human cyclin E is associated with a periodic $\mathrm{G} 1$ protein kinase. Science (in press).

Evans, T., E.T. Rosenthal, J. Youngblom, D. Distel, and T. Hunt. 1983. Cyclin: A protein specified by maternal mRNA in sea urchin eggs that is destroyed at each cleavage division. Cell 33: 389-396.

Ewen, M., Y. Xing, L.J.B., and D. Livingston. 1991. Molecular cloning, chromosonal mapping, and expression of the cDNA for $\mathrm{p} 107$, a retinoblastoma gene product-related protein. Cell 66: 1155-1164.

Faha, B., M. Ewen, L.-H. Tsai, D. Livingston, and E. Harlow. 1992a. Interaction between human cyclin A and adenovirus E1A-associated p107 protein. Science 255: 87-90.

Faha, B., M. Meyerson, and L.-H. Tsai. 1992b. Adenovirus E1A 
targets one of two cyclin A-kinase complexes. Pezcoller Found. Symp. (in press).

Giordano, A., P. Whyte, E. Harlow, B.J. Franza, D. Beach, and G. Draetta. 1989. A $60 \mathrm{kD}$ cdc2-associated polypeptide complexes with the E1A proteins in adenovinus-infected cells. Cell 58: 981-990.

Girard, F., U. Strausfeld, A. Fernandez, and N. Lamb. 1991. Cyclin A is required for the onset of DNA replication in mammalian fibroblasts. Cell 67: 1169-1179.

Hadwiger, J.A., C. Wittenberg, H.E. Richardson, M.A. de Barros Lopes, and S.I. Reed. 1989. A family of cyclin homologs that control the Gl phase in yeast. Proc. Natl. Acad. Sci. 86: 6255-6259.

Harlow, E. and D. Lane. 1988. Antibodies: A laboratory manual. Cold Spring Harbor Laboratory, Cold Spring Harbor, New York.

Harlow, E., L.V. Crawford, D.C. Pim, and N.M. Williamson. 1981. Monoclonal antibodies specific for simian virus 40 tumor antigens. J. Virol. 39: 861-869.

Harlow, E., B.J. Franza, and C. Schley. 1985. Monoclonal antibodies specific for adenovirus early region lA proteins: Extensive heterogeneity in early region 1 A products. $/$. Virol. 55: 533-546.

Hartwell, L.H. 1973. Three additional genes required for deoxyribonucleic acid synthesis in Saccharomyces cerevisiae. J. Bacteriol. 115: 966-974.

Herrmann, C., L.-K. Su, and E. Harlow . 1991. Adenovirus E1A is associated with a serine/threonine protein kinase. J. Virol. 65: 5848-5859.

Hiebert, S.W., M. Lipp, and J.R. Nevins. 1989. ElA-dependent trans-activation of the human MYC promoter is mediated by the E2F factor. Proc. Natl. Acad. Sci. 86: 3594-3598.

Hiebert, S.W., M. Blake, J. Azizkhan, and J.R. Nevins. 1991a. Role of E2F transcription factor in E1A-mediated trans-activation of cellular genes. I. Virol. 65: 3547-3552.

Hiebert, S.W., S.P. Chellappan, J.M. Horowitz, and J.R. Nevins. $1991 \mathrm{~b}$. The interaction of $\mathrm{pRb}$ with $\mathrm{E} 2 \mathrm{~F}$ inhibits the transcriptional activity of E2F. Genes \& Dev. 6: 177-185

Hu, Q., C. Bautista, G. Edwards, D. Defeo-Jones, R. Jones, and E. Harlow. 1991. Antibodies specific for the human retinoblastoma protein identify a family of related polypepides. Mol. Cell. Biol. 11: 5792-5799.

Hunt, T., F.C. Luca, and J.V. Ruderman. 1992. The requirements for protein synthesis and degradation, and the control of destruction of cyclins A and B in the meiotic and mitotic cell cycles in the clam embryo. J. Cell.Biol. (in press).

Koff, A., F. Cross, A. Fisher, J. Schumacher, K. Leguellec, M. Philippe, and J.M. Roberts. 1991. Human cyclin E, a new cyclin that interacts with two members of the CDC2 gene family. Cell 66: 1217-1228.

Laiho, M., J.A. DeCaprio, J.W. Ludlow, D.M. Livingston, and J. Massague. 1990. Growth inhibition by TGF-beta linked to suppression of retinoblastoma protein phosphorylation. Cell 62: 175-185.

Lalande, M. 1990. A reversible arrest point in the late Gl phase of the mammalian cell cycle. Exp. Cell Res. 186: 332-339.

Lehner, C.F. and P.H. O'Farrell. 1990. The roles of Drosophila cyclins A and B in mitotic control. Cell 61: 535-547.

Lew, D.J., V. Dulic, and S.I. Reed. 1991. Isolation of three novel human cyclins by rescue of Gl cyclin $(C L N)$ function in yeast. Cell 66: 1197-1206.

Matsushime, H., M.F. Roussel, R.A. Ashmun, and C.J. Sherr. 1991. Colony-stimulating factor 1 regulates novel cyclins during the G1 phase of the cell cycle. Cell 65: 701-713.

Minshull, J., J.J. Blow, and T. Hunt. 1989. Translation of cyclin mRNA is necessary for extracts of activated Xenopus eggs to enter mitosis. Cell 56: 947-956.

Moreno, S., J. Hayles, and P. Nurse. 1989. Regulation of p34cdc2 protein kinase during mitosis. Cell 58: 361-372.

Motokura, T., T. Bloom, H.G. Kim, H. Juppner, J.V. Ruderman, H.M. Kronenberg, and A. Arnold. 1991. A novel cyclin encoded by a bcll-linked candidate oncogene. Nature 350: 512-515.

Mudryj, M., S.W. Hiebert, and J.R. Nevins. 1990. A role for the adenovirus inducible E2F transcription factor in a proliferation dependent signal transduction pathway. EMBO $J$. 9: 2179-2184.

Mudryi, M., S.H. Devoto, S.W. Hiebert, T. Hunter, J. Pines, and J.R. Nevins. 1991. Cell cycle regulation of the E2F transcription factor involves an interaction with cyclin A. Cell 65: $1243-1253$.

Murray, A.W., M.J. Solomon, and M.W. Kirschner. 1989. The role of cyclin synthesis and degradation in the control of maturation promoting factor activity. Nature 339: 280-286.

Nash, R., G. Tokiwa, S. Anand, K. Erickson, and A.B. Futcher. 1988. The WHI1 + gene of Saccharomyces cerevisiae tethers cell division to cell size and is a cyclin homolog. EMBO I. 7: 4335-4346.

Nurse, P. 1975. Genetic control of cell size at cell division in yeast. Nature 256: 457-451.

Nurse, P. and Y. Bissett. 1981. Gene required in Gl for commitment to cell cycle and in G2 for control of mitosis in fission yeast. Nature 292: 558-560.

Pagano, M., G. Draetta, and P. Jansen-Durr. 1992a. Association of cdk2 kinase with the transcription factor E2F during $S$ phase. Science 255: 1144-1147.

Pagano, M., R. Pepperkok, F. Verde, W. Ansorge, and G. Draetta. $1992 \mathrm{~b}$. Cyclin A is required at two points in the human cell cycle. EMBO J. 11: 961-971.

Pardee, A.B. 1989. Gl events and regulation of cell proliferation. Science 246: 603-608.

Pietenpol, J.A., R.W. Stein, E. Moran, P. Yaciuk, R. Schlegel, R.M. Lyons, M.R. Pittelkow, K. Munger, P.M. Howley, and H.L. Moses. 1990. TGF-beta 1 inhibition of c-myc transcription and growth in keratinocytes is abrogated by viral transforming proteins with pRB binding domains. Cell 61: 777785

Piggott, J.R., R. Rai, and B.L. Carter. 1982. A bifunctional gene product involved in two phases of the yeast cell cycle. $\mathrm{Na}$ ture 298: 391-393.

Pines, J. and T. Hunter. 1990. Human cyclin A is adenovirus ElA-associated protein $\mathrm{p} 60$ and behaves differently from cyclin B. Nature 346: 760-763.

Rao, P.N. and R.T. Johnson. 1970. Mammalian cell fusion: Studies on the regulation of DNA synthesis and mitosis. Nature 225: 159-164.

Raychaudhuri, P., R. Rooney, and J.R. Nevins. 1987. Identification of an E1A-inducible cellular factor that interacts with regulatory sequences within the adenovirus E4 promoter. EMBO I. 6: 4073-4081.

Raychaudhuri, P., S. Bagchi, S.H. Devoto, V.B. Kraus, E. Moran and J.R. Nevins. 1991. Domains of the adenovirus E1A protein that are required for oncogenic activity are also required for dissociation of E2F transcription factor complexes. Genes \& Dev. 5: 1200-1211.

Reed, S.I. 1991. G1 specific cyclins: In search of an S-phase promoting factor. Trends Genet. 7: 95-99.

Reed, S.I. and C. Wittenberg. 1990. Mitotic role for the Cdc28 protein kinase of Saccharomyces cerevisiae. Proc. Nat1. Acad. Sci. 87: 5697-5701.

Richardson, H.E., C. Wittenberg, F. Cross, and S.I. Reed. 1989. An essential G1 function for cyclin-like proteins in yeast. 
Cell 59: 1127-1133.

Rosenblatt, J., Y. Gu, and D.O. Morgan. 1992. Human cyclindependent kinase 2 is activated during the $S$ and $G 2$ phases of the cell cycle and associates with cyclin A. Proc. Natl. Acad. Sci. 89: 2824-2828.

Sambrook, J., E.F. Fritsch, and T. Maniatis. 1989. Molecular cloning: A laboratory manual. Cold Spring Harbor Laboratory Press, Cold Spring Harbor, New York.

Shirodkar, S., M. Ewen, J.A. DeCaprio, D. Morgan, D. Livingston, and T. Chittenden. 1992. The transcription factor E2F interacts with the retinoblastoma product and a p107-cyclin A complex in a cell cycle-regulated manner. Cell 68: 157166.

Smith, D.B. and K.S. Johnson. 1988. Single-step purification of polypeptides expressed in Escherichia coli as fusions with glutathione S-transferase. Gene 67: 31-40.

Solomon, M.J., M. Glotzer, T.H. Lee, M. Phillipe, and M.W. Kirschner. 1990. Cyclin activation of p34cdc2. Cell 63: 1013-1024.

Standart, N., J. Minshull, J. Pines, and T. Hunt. 1987. Cyclin synthesis, modification and destruction during meiotic maturation of the starfish oocyte. Dev. Biol. 124: 248-258.

Studier, F.W., A.H. Rosenberg, J.J. Dunn, and J.W. Dubendorff. 1990. Use of T7 RNA polymerase to direct the expression of cloned genes. Methods Enzymol. 185: 60-89.

Swenson, K.I., K.M. Farrell, and J.V. Ruderman. 1986. The clam embryo protein cyclin $A$ induces entry into $M$ phase and the resumption of meiosis in Xenopus oocytes. Cell 47: 861870.

Tsai, L., E. Harlow, and M. Meyerson. 1991. Isolation of the human cdk2 gene that encodes the cyclin $\mathrm{A}$ - and adenovirus E1A-associated p33 kinase. Nature 353: 174-177.

Walker, D. and J.L. Maller. 1991. Role for cyclin A in the dependence of mitosis on completion of DNA replication. $\mathrm{Na}$ ture 354: 314-317.

Wittenberg, C., K. Sugimoto, and S.I. Reed. 1990. G1-specific cyclins of S. cerevisiae: Cell cycle periodicity, regulation by mating pheromone, and association with the p34CDC28 protein kinase. Cell 62: 225-237.

Xiong, Y., T. Connolly, B. Futcher and D. Beach. 1991. Human D-type cyclin. Cell 65: 69l-699.

Yee, A.S., R. Reichel, I. Kovesdi, and J.R. Nevins. 1987. Promoter interaction of the E1A-inducible factor E2F and its potential role in the formation of a multi-component complex. EMBO I. 6: 2061-2068. 


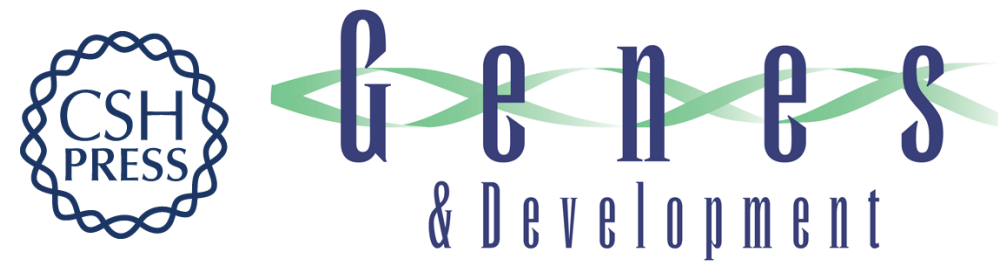

\section{Cyclin E/cdk2 and cyclin A/cdk2 kinases associate with p107 and E2F in a temporally distinct manner.}

E Lees, B Faha, V Dulic, et al.

Genes Dev. 1992, 6:

Access the most recent version at doi:10.1101/gad.6.10.1874

References This article cites 64 articles, 16 of which can be accessed free at:

http://genesdev.cshlp.org/content/6/10/1874.full.html\#ref-list-1

License

Email Alerting

Service

Receive free email alerts when new articles cite this article - sign up in the box at the top right corner of the article or click here.

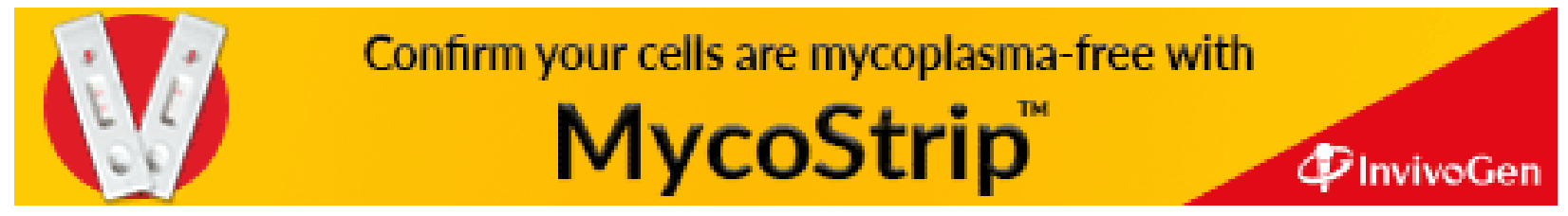

